DOI 10.37882/2223-2982.2020.04.34

\title{
ЭВАКУИРОВАННОЕ НАСЕЛЕНИЕ В МАРИЙСКОЙ АССР В ГОДЫ ВЕЛИКОЙ ОТЕЧЕСТВЕННОЙ ВОЙНЫ: ПРОБЛЕМЫ РАЗМЕЩЕНИЯ, СОЦИАЛЬНОЙ АДАПТАЦИИ И ТРУДОВОЙ ДЕЯТЕЛЬНОСТИ С МЕСТНЫМ НАСЕЛЕНИЕМ Йошкар-Ола \\ kristina-ingvar@mail.ru
}

\section{THE EVACUATED POPULATION IN THE MARI AUTONOMOUS SOVIET SOCIALIST REPUBLIC DURING THE GREAT PATRIOTIC WAR: PROBLEMS OF ACCOMMODATION, SOCIAL ADAPTATION AND LABOR ACTIVITY WITH THE LOCAL POPULATION}

\section{K. Fedorova}

Summary: Relevance and goals. The events of the Great Patriotic War are specifically devoted to the regional history of the Mari ASSR in 1941-1945. The article discusses the mechanism of the evacuation process in the rear region of the Mari Republic. In solving all the problems was assigned to the functional activities of the Council of People's Commissars of the Mari ASSR. The purpose of the work is to reflect the process of displacement, social adaptation and labor activity of the evacuated population in the Mari ASSR during the war years 1941-1945.

Materials and methods. The implementation of research tasks was achieved through the use of documents extracted from the funds of the State Archive of the Republic of Mari El. The methodological potential includes the philosophical principles of dialectics, namely objectivity, scientificness, comprehensiveness. In the implementation of these principles, she helped to study documentary sources related to identifying the features of the evacuation process during the Great Patriotic War. Results. Research activities of the Council of People's Commissars of the Mari ASSR in 1941-1945 for evacuated citizens revealed the creation of an evacuation unit as part of the MSSR SNK, an increase in the functional powers of the government. SNK MASSR solved all the problems that arise regarding the evacuated population in the Mari Territory.

Findings. During the years of World War II, the Council of People's Commissars of the Mari Autonomous Soviet Socialist Republic during the study of archival documents on the evacuation process of the population: solved problems in the field of employment, social adaptation and accommodation of evacuated citizens in the republic, responded to complaints and provided assistance.

Keywords: Mari Autonomous Soviet Socialist Republic, the Great Patriotic War, evacuated population, accommodation, social adaptation, labor.
$\mathrm{H}$ ачало Великой Отечественной войны изменил повседневный жизненный уклад всего Советского Союза. Люди столкнулись войной лицом к лицу. Из оккупированной территории в тыловые регионы нашей страны активно эвакуировались промышленные пред-
Аннотация: Актуальность и цели. События Великой Отечественной войны, конкретно посвящены региональной истории Марийской АССР в 1941-1945 года. В статье рассматривается механизм эвакуационного процесса в тыловой регион Марийской республики. В решении всех проблем было возложено в функциональную деятельность Совета Народных Комиссаров Марийской АССР. Цель работы - отразить процесс перемещения, социальной адаптации и трудовой деятельности эвакуированного населения в Марийскую АССР в годы войны 1941-1945 гг.

Материалы и методы. Реализация исследовательских задач была достигнута на основе использования документов, извлеченных из фондов Государственного архива Республики Марий Эл. Методологический потенциал включает философские принципы диалектики, а именно объективность, научность, всесторонность. В реализации этих принципов помогла провести изучение документальных источников, связанных с выявлением особенностей эвакуационного процесса в годы Великой Отечественной войны.

Результаты. Исследовательская деятельность Совета Народных Комиссаров Марийской АССР в 1941-1945 гг. по эвакуированным гражданам выявило создание в составе СНК МАССР эвакопунка, увеличение функциональных полномочий органа государственного управления. СНК МАССР решало все возникающие проблемы, касающиеся эвакуированного населения в Марийском крае.

Выводы. За годы Великой Отечественной войны Совет Народных Комиссаров Марийской АССР в ходе изучения архивных документов по эвакуационному процессу населения: решал проблемы в области трудоустройства, социальной адаптации и размещения эвакуированных граждан в республике, реагировал на жалобы и оказывал помощь.

Ключевые слова: Марийская АССР, Великая Отечественная война, эвакуированное население, размещение, социальная адаптация, трудовая деятельность.

приятия и само население. Эвакуация шла через железнодорожную сеть и распределялась по регионам.

Марийский край входил в зону тыловой части СССР. Главной базой приема эвакуированного населения ста- 
ла столица, город Йошкар-Ола, Марийской АССР, где в июле 1941 года был создан эвакуационный пункт. На территорию Республики Марий Эл, по железнодорожной транспортной сети, принимали эвакуированное население из Новгородской, Псковской, Великолукской, Ленинградской, Калининградской и других областей. Большая часть населения распределялась в сельскую местность.

Цель статьи - исследование организации и комплекса проблем эвакуированного населения в Марийском крае в годы Великой Отечественной войны (1941-1945 гг.).

Для достижения поставленной цели следует решить несколько задач: показать способы размещения и материального обеспечения эвакуированного населения в Марийской АССР, изучить особенности социальной адаптации и трудовой деятельности мигрантов с коренным населением Марийской республики.

Источниковую базу данной статьи составляют опубликованные и архивные документы. Опубликованный материал содержится в изданных сборниках документов. Интерес для изучения темы военного времени служит энциклопедия «Великая Отечественная война. 1941-1945.» [1]. Некоторые сведения о заботе об эвакуированном населении кратко раскрываются во втором томе Истории Марийской АССР [2], изданного в 1987 году. В 2005 году выходит сборник документов и материалов [3] по истории Марийского края в годы Великой Отечественной войны, в которой опубликованы архивные материалы военного времени органов государственной власти и управления и вклад мирного населения в победу над фашизмом.

В настоящее время изданы монографии Кошкиной О.А. [4]и Васенина Д.В. [5], изучающие вклад населения в развитии сельского хозяйства и промышленности Марийской АССР в годы Великой Отечественной войны.

Особую роль в изучении и раскрытии темы эвакуированного населения являются первоисточники. Архивы Республики Марий Эл хранят в своем фонде еще неизученные документы военной эпохи. В данной статье использованы материалы архивного фонда Р-542: постановления и распоряжения Совета Народных Комиссаров Марийской АССР 1941-1945 гг.

Первая волна эвакуации из фронтовых частей коснулась главным образом перемещением скота и промышленных предприятий оборонного комплекса страны в тыловые регионы нашей Родины.

На территорию Марийского края с эвакуированным населением был эвакуирован скот. Первым делом скот был распределен по местным колхозам, которые могли содержать их в определенном количестве.

С 20 сентября 1941 года, на территории Марийского края шло распределение кредитов на строительство временных помещений для эвакуированного скота. Сельскохозяйственный банк предоставил распределение кредита по районам в сумме 460 тысяч рублей, отпущенных на строительство и приспособление временных помещений для эвакуированного скота: Йошкар-Олинского, Оршанского, Пектубаевского, Ново-Торъяльского, Ронгинского, Куженеркого, Сернурского, Косолаповского, Мари-Турекского, Парангинского, Моркинского, Сотнурского, Еласовского, Юринского, Килемарского, Горно-Марийского районов [6, л. 15].

Эвакуированное население распределялось по всей республике Марий Эл. На расходы, связанные с прибытием эвакуированного населения, государство ассигновало из республиканского бюджета - 50 тысяч рублей [7, л. 167]. Большинство населения жило за чертой города. Совет Народных Комиссаров Марийской АССР от 10 октября 1941 №796 [8, л. 122], проводило проверки жилищно-бытовых условий, проживающих в сельской местности эвакуированного населения. По результатам проверки были установлены крупные недостатки. За каждым колхозом были прикреплены жилые дома, где временно проживали эвакуированные. Колхоз должен был курировать и контролировать осуществляющий ремонт и утепление помещений, также был ответственным за заготовку топлива. Оказывал соответствующую помощь в приобретении теплой одежды и обуви, продуктов питания.

Эвакуированное население привлекалось на сельскохозяйственные работы. Некоторые обустраивались в колхозы. Совет Народных Комиссаров Марийской АССР вел учет своевременного начисления и выдачи на трудодни, заработанные эвакуированными в колхозах продукты, и одновременно с этим выделялись продукты питания в виде: хлеба, картошки, овощей, молока и т.д.

Некоторые колхозы своевременно вели отчет о ходе размещения и содержания эвакуированного скота. Например, в колхозе «Смена» Княжнинского сельского совета поступившие 25 голов крупного рогатого скота размещены в открытых помещениях, «Передовик» там же поступившие 4 лошади, 50 голов крупного рогатого скота и 74 голов овец [9, л. 41].

В январе 1942 года в одном из протоколов СНК Марийской АССР [10, л. 45]., руководство отделом Марийской республики должны вести учет эвакуированного населения. Данное мероприятие в городах и районах Марийской АССР ведут исполнительные комитеты городских, районных, поселковых и сельских советов депутатов трудящихся. В их организационную деятельность 
включается функция введения справочной картотеки на всех эвакуированных граждан, размещенных на территории республики.

Следующей задачей Совета Народных Комиссаров Марийской АССР от 13 марта 1942 года, было решение «Об устройстве детей, оставшихся без родителей» [11, л. 344]. В решении данной задачи возлагалось на исполнительные комитеты городских, районных, поселковых и сельских депутатов трудящихся под личную ответственность председателей, которые должны обеспечить устройство детей, оставшихся сиротами или потерявших родителей при переезде на другую местность. Все другие (без надворные) распределяются с помощью НКВД Марийской АССР в приемники. Дети до 15 лет направляются в приемники-распределители, где они находятся в течение двух недель. Дети, оставшиеся без родителей, в возрасте до 14 лет направляются через органы Народного Образования в детские учреждения или на патронирование, а дети старше 14 лет устраиваются на работу в промышленные предприятия или на сельское хозяйство НКВД Марийской АССР по разверстке Наркомпроса Марийской АССР. Лица принявшие (патронат) детей, получают ежемесячное пособие-50 рублей, и всех детей НКВД ставит на учет в справочно-адресных детский столах $[12$, л. 344].

Эвакуированное население, проживающее на территории Марийского края, неоднократно подавали жалобы в исполнительные комитеты районных советов депутатов трудящихся и в другие организации, но рассмотрение их дел было несвоевременным, а в отдельных случаях нетронутые до 4х месяцев. При проверке СНК Марийской АССР ряда районов (Пектубаевского, НовоТоръяльского, Йошкар-Олинского и др.) установил, что исполкомы Райсоветов, Райкомы ВКП(б) крайне неудовлетворительно занимаются вопросами трудоустройства и созданием материально-бытовых условий для эвакуированного населения, размещенного в районах Марийской АССР, в результате 35\% не исполняются на работах В сельском хозяйстве и промышленности. В ряде колхозов отдельным семьям эвакуированных заселенных, в порядке уплотнения, в дома колхозников, владельцы этих домов создали невыносимые условия для проживания, запрещая пользоваться печью, погребом и другими бытовыми объектами; Шулкинское сельпо Оршанского района, Ронгинское сельпо Ронгинского района в течение двух месяцев не выдавали детям эвакуированных хлеба [13, л. 144].

Проверка установила, в ряде районов не были решены прежние вопросы: в утеплении жилищ, занимаемых эвакуированным населением, не организована заготовка и вывозка топлива, нет помощи в приобретении теплой одежды и обуви. Совет Народных Комиссаров Марийской АССР обязал товарища Локтева принять не- обходимые меры в устранении проблем, и предложил Стройтресту отремонтировать общежитие для эвакуированного населения (клуб железнодорожников, расположенного в городе Йошкар-Ола).

В декабре 1942 года в решении исполнительного комитета Йошкар-Олинского Городского Совета депутатов трудящихся на строительство жилищ упрощенного типа. В соответствии СНК СССР от 10 июля 1942 года за №1353, сроком на два месяца в порядке трудовой помощи привлечь местное и эвакуированное население в количестве-160 человек: Йошкар-Ола-15, Оршанский-15, Сернурский-20, Параньгинский-25, Косолаповский-20, Мари-Турекский-40, Куженерский-25 [14, л. 290].

Практику строительства жилых зданий по упрощенному типу конструкции на территории Марийского края стали применять с мая 1942 года. В целях быстрого увеличения жилищного фонда в городах и районных центрах Марийской республики удешевления стоимости строительства, сокращения транспортных средств, квалификационной рабочей силы и потребности в строительных материалах [15, л. 127]. Совет Народных Комиссаров обязал руководителей колхозных организаций и председателей исполнительных комитетов районных и городских советов, практику широкого внедрения строительства жилых зданий по упрощенному типу: каркасно-вальковые, саманные, глинобитные и др.

С начала 1943 года утверждается план о заготовках картофеля и овощей для эвакуированного населения. Организацию по вопросам заготовки было возложено на Марпотребсоюз под персональную ответственность председателя товарища Швалева. По утвержденному плану, от 3 января 1943 года [16, л. 24], для удовлетворения потребностей эвакуированного населения в количестве 1327 тонн картофеля и овощей, с распределением по районам.

Из фонда государственного бюджета на оказание единовременной помощи эвакуированному населению было выделено 25 тысяч рублей. При проведении проверки СНК Марийской АССР о расходовании средств исполнительным комитетом Йошкар-Олинского Городского Совета было установлено, что сумма расходовалась без учета нуждаемости и без предварительной проверки материальных условий проживания эвакуированных семей. Исполком Горсовета средства, предназначенные для эвакуированных, распределил по отделам Горсовета, в результате чего 5450 рублей израсходовано незаконно, в том числе выдано местному населению 2400 рублей; кроме того, выданные 1776 рублей не подтверждены документами [17, л. 79].

В состав эвакуированного населения включались и семьи военнослужащих, но они по сравнению от других 
имели ряд преимуществ. Семьям военнослужащих разрабатывали конкретные мероприятия по устройству их на работу. Кроме этого, устанавливался контроль за работой исполнительных комитетов сельских и поселковых советов депутатов трудящихся по решению этого вопроса. СНК Марийской АССР обязал все учреждения, предприятия, совхозы, колхозы, артели инвалидов, кустарно-промысловые кооперативы республики, предоставить работу членам семей военнослужащих в соответствии с их квалификацией и по месту жительства [18, л. 44].

Следующим отличием становится выплата пособий семьям военнослужащих и пенсий инвалидам Отечественной войны. Наркомсобес производит выплату в Йошкар-Оле по городскому отделу социального обеспечения населения. Отдельно от городских единовременные пайки выдаются семьям военнослужащих, эвакуированных в сельскую местность. Так, СНК СССР установил срок выдачи для сельской местности 8 мая 1943 года, но на территории республики он был сорван. Мари-Турекский, Звениговский, Сернурский и другие районы до сего времени не приступили к выдаче единовременного пайка, а Оршанский, Куженерский, Горно-Марийский и Еласовские районы по состоянию на 17 мая не вывезли выделенные им для этой цели продукты с базы Марпотребсоюза [19, л. 92].

В соответствии с постановлением СНК РСФСР от 30 января 1943 года №102 устанавливаются требования по государственному обеспечению и бытовых условий для семей военнослужащих: «обеспечение пособиями и пенсиями семей военнослужащих рядового и младшего состава Красной Армии и Военно-Морского флота; трудового устройства и проведения мероприятий по удовлетворению материально-бытовых нужд семей военнослужащих рядового и начальственного состава; обеспечение семьям военнослужащих установленных для них льгот; рассмотрение заявлений и жалоб, поступивших от семей военнослужащих, и принятие по ним необходимых мер [20, л. 314-315]».

Эвакуированное население, так же как и местное, было заинтересованно в помощи государству. Все, кроме беременных, матерей с детьми и государственных служащих, нетрудостроенное население было мобилизовано на выполнение сельскохозяйственных работ, на выполнение плана по дровозаготовке для железной дороги, для сплавных работ и т.д. Так, в соответствии с постановлением от 12 марта 1943 года №3031 было мобилизовано на лесосплавные работы - выгрузку древесины в навигации из числа местного населения мужчин в возрасте от 16 до 55 лет и женщин от 18 до 45 лет для сплавных предприятий $[21$, л. 78]. В летнее время трудоспособное население городов, рабочих поселков и сельские жители направлялись в прополочные работы и сеноуборку в Марийской АССР.
Эвакуированное население находилось в трудном положении: проблемы в размещении, адаптации с местным населением. Все жизненные сложности решались силами матерей, которые остались без помощи родных и близких, с детьми на руках. Новое место жительства и проблемы в размещении и обеспечении семей, без средств существования влекло на смертельный шаг.

На заседании Совета Народных Комиссаров Марийской АССР от 27 июня 1944 года решался вопрос о факте самоубийства члена семьи военнослужащего. Семья погибшего фронтовика, колхозника колхоза имени Калинина товарища Горбунова, имевшего трех детей от 3-х до 13 лет, 15 июня 1944 года покончила жизнь самоубийством $[22$, л. 358]. Причиной смерти послужило неоднократное обращение товарища Горуновой за оказанием помощи в районный исполнительный комитет к заведующему отделу по государственному обеспечению т. Мамаеву, но не получившей удовлетворительного ответа.

По мере отступления вражеских войск на запад, с августа 1944 года из территории Марийской республики В соответствии с распоряжением СНК СССР начинается реэвакуация населения: в Калининградскую область, в Ленинградскую область, в Эстонскую АССР. Эвакуированное население возвращается на прежнее место жительства граждан, кроме тех, кто не работает на предприятии оборонной промышленности, а также в системе НКО СССР, НКВД СССР.

Таким образом, Великая Отечественная война изменила жизненный уклад всей страны целом. В государстве существовало две части: фронт и тыл. В условиях войны в тыловую часть нашей страны шла массовая эвакуация населения, промышленных предприятий и скота.

Автономные республики, принимавшие на свою территорию эвакуированное население и предприятия, летом 1941 года создавали структурные органы, которые в дальнейшем видоизменялись. В Марийской АССР стояла проблема в размещении прибывавшего населения, как для органов государственной власти, так и для местного населения. В начальный этап Великой Отечественной войны не существовало определенной схемы организации эвакуации населения в Среднее Поволжье в целом. Государство при эвакуации не рассматривало интересы и потребности людей, главная цель состояла в сохранении жизни каждого человека.

Остро стояла проблема в продовольственном снабжении эвакуированного населения, т.к. большая часть продукции шла на нужды фронта. В городах эвакуированное население приобретало продукты питания по карточкам, в сельской местности по трудодням. Некоторым категориям населения осуществлялась государственная помощь в виде единовременных денежных пособий. В сельской местности эвакуированные имели 
индивидуальные хозяйства, но их, как и местное население привлекали в обязательной сдаче сельхозпродукции для Красной Армии. В годы войны оставалась проблема в снабжении переселенцев предметами первой необходимости (теплая одежда, обувь, мыло и т.д.).

Марийская АССР улучшало материальное положение эвакуированного населения в предоставлении рабочих мест. В первую очередь трудоустраивались те, рабочие, которые эвакуировались вместе с промышленными предприятиями оборонного комплекса. Так же в эту категорию относятся семьи руководителей крупных промышленных предприятий, парт руководителей и члены семей военнослужащих.

Эвакуированное население, размещенное в сельской местности, обустраивалось по своим специальностям, колхозам, совхозам и промысловым артелям. Но не трудоустройство коснулось женщин, имеющих малолетних детей, т.к. отсутствовали свободные места в детские сады. Были те, которые не имели теплые одежды в холодное время года. Инвалиды и пенсионеры в силу отсутствия определенной профессиональной деятель- ности. Но в этой ситуации помогали местные жители.

Проблемы эвакуированного населения в социальной адаптации с местными жителями данного региона. С началом Великой Отечественной войны разделились на два фронта: первая категория - помогало в размещении и обустройстве переселенцев, а вторая категория граждан утверждала, что они ущемляют их права. Ко второй категории относятся и те должностные лица государственного управления, которые с опозданием реагировали на жалобы и просьбы эвакуированного населения.

Более слаженная и структурированная работа осуществлялась в реэвакуации граждан в родные республики.

За годы Великой Отечественной войны Совет Народных Комиссаров Марийской АССР в полном объеме выполнил свои должностные обязательства. СНК МАССР в своем составе создавал отделы по эвакуации населения. Контролировал размещение эвакуированных граждан, обеспечивал их трудоустройство, продуктами питания, временным жильем и медицинским обслуживанием.

\section{ЛИТЕРАТУРА}

1. Великая Отечественная война, 1941-1945: энциклопедия. М.: Советская энциклопедия, 1985. - 832 с.

2. История Марийской АССР. Т.2: Эпоха социализма (1917-1987) / А.В. Хлебников, В.Ф. Пашуков, А.Р. Смиренский [и др.] / под ред. А.В. Хлебникова. - Йошкар-0ла: Марийское книжное издательство, 1987. - 326 с.

3. Марийская АССР в годы Великой Отечественной войны 1941-1945 гг.: Сборник документов и материалов. - Йошкар-0ла: Комитет РМЭ по делам архивов, Государственный Архив Республики Марий Эл, 2005. - 496 с.

4. Кошкина 0.А. Сельское хозяйство и колхозное крестьянство Марийской АССР в годы Великой Отечественной войны (1941-1945 гг.). - Йошкар-0ла: МариНИИ, 2010. - 248 с.

5. Васенин Д.В. Промышленность и рабочие Марийской АССР в период Великой Отечественной войны (1941-1945 гг.). - Йошкар-0ла: Поволжский государственный университет, 2014. - 204 с.

6. Государственный архив Республики Марий Эл Ф. Р-542. Оп. 4. Д. 52.

7. осударственный архив Республики Марий Эл Ф. Р-542. Оп. 4. Д. 48.

8. Государственный архив Республики Марий Эл Ф. Р-542. Оп. 4. Д. 53.

9. Государственный архив Республики Марий Эл Ф. Р- 542. ОП. 4. Д. 58.

10. Государственный архив Республики Марий Эл Ф. Р-542. Оп. 4. Д. 113.

11. Государственный архив Республики Марий Эл Ф. Р-542. Оп. 4. Д. 113.

12. Государственный архив Республики Марий Эл Ф. Р-542. Оп. 4. Д. 113.

13. Государственный архив Республики Марий Эл Ф. Р-542. Оп. 4. Д. 116.

14. Государственный архив Республики Марий Эл Ф. Р-542. Оп. 4. Д. $116 а$.

15. Государственный архив Республики Марий Эл Ф. Р-542. Оп. 4. Д. 114.

16. Государственный архив Республики Марий Эл Ф. Р-542. Оп. 4. Д. 173.

17. Государственный архив Республики Марий Эл Ф. Р-542. Оп. 4. Д. 174.

18. Государственный архив Республики Марий Эл Ф. Р-542. Оп. 4. Д. 113.

19. Государственный архив Республики Марий Эл Ф. Р-542. 0п. 4. Д. 174а.

20. Государственный архив Республики Марий Эл Ф. Р-542. Оп. 4. Д. 173.

21. Государственный архив Республики Марий Эл Ф. Р-542. Оп. 4. Д. 174.

22. Государственный архив Республики Марий Эл Ф. Р-542. Оп. 4. Д 241 а.

(c) Федорова Кристина Игоревна (kristina-ingvar@mail.ru). 